\title{
Blackfellas rapping, breaking and writing: a short history of Aboriginal hip hop
}

\author{
Tony Mitchell
}

\section{Munki Mark: 'The architect of Aboriginal hip hop'}

The history of hip hop in Australia is largely a question of often competing oral histories of local developments in various places. It began with breakdancing, largely inspired by Malcolm McLaren's 1983 video clip Buffalo gals, which was followed by outbreaks of graffiti writing, inspired by Charlie Ahearn's 1982 film Style wars. Rapping, rhyming and DJ-ing followed on, partly encouraged by Stan Latham's 1984 film Beat street, and recordings by Kool Herc, Grandmaster Flash, Africa Bambaata and other pioneers of what at the time was a predominantly African-American musical idiom.

Ian Maxwell's book Phat beats, dope rhymes is an ethnographic study of hip hop in Sydney from 1992 to 1994, which focuses mostly on Def Wish Cast, Sound Unlimited and other western Sydney crews, filtering a lot of his historicisation through authority figures in the scene such as Blaze and Miguel D'Souza. One of the myths of origin for Sydney hip hop that Maxwell notes is the scene which took place in Burwood Park in 1983, with breakdancing crews such as the Westside Posse, later Sound Unlimited, representing a multicultural gathering of the faithful, many of them coming by train from east Sydney. As Sound Unlimited put it in their track 'Tales from the Westside': 'Let's get back / I'll start at Burwood park / hip hop breakin' after dark / many crews would join the fray / travel from east to west upon the train / some to break some to inflict pain. ${ }^{1}$ Maxwell provides accounts for only two examples of Aboriginal hip hop, both female crews, in the early 1990s who never recorded, and whose names he mis-spells. He describes performances by the 'Aranta' (Arrernte) Desert Posse, who combined traditional dance with a rather artifical enactment of rap at the Powerhouse Museum in Sydney, and quotes lyrics about Aboriginal genocide from the short-lived duo 'Black Justice' (Blakjustis), a Redfern-based crew who recounted to him Public Enemy's rather tokenistic attempts to communicate with Redfern youth. Maxwell then quotes local luminary Blaze to the effect that Blakjustis were 'not really Hip Hop' ${ }^{2}$ and after noting the widespread appeal of African-American hip hop to Aboriginal youth, although it was yet to sell as many records as country and western, moves on to broader questions of class and ethnicity. Maxwell's account is not at all reprehensible, but it demonstrates

1. Sound Unlimited 1992. See also Maxwell 2003.

2. Maxwell 2003: 68 . 
the invisibility of Aboriginal involvement in the early days of Sydney hip hop, an invisibility which has recently begun to be redressed.

Morganics, Australia's most ubiquitous MC, beat boxer and breaker, an AngloAustralian former actor and theatre director who has been a mentor and producer to many fledgling Aboriginal hip hop artists all around the country since the late 1990s, was another early participant in Sydney hip hop. He began breakdancing in Circular Quay in 1984, later linking up with Lebanese-Australian MC Sleek the Elite on Oxford Street. But Bankstown-based Aboriginal MC Munki Mark's recollections of Aboriginal hip hop, which begin in Redfern in 1982 with breakdancing, a graffiti crew called Black Connection, and later some MC-ing and rhyming, suggests the Indigenous hip hop scene may have got there first. Usually invisible and inaudible in the many debates and oral histories which have taken place over the years in the mainstream media, the music street press and numerous website forums about Australian hip hop, MC-ing by Aboriginal practitioners is starting to emerge into the light. The 2005 Deadly Award Best New Group winners, Newcastle-based Local Knowledge, arguably achieved the highest profile before their unfortunate breakup in mid-2006. Actor-MC BrothaBlack (Shannon Williams), Murri MC and producer Lez Beckett, winner of a 2005 Deadly Award for most promising new talent, with his new crew Cypher Duem, and Ebony Williams, Sydney 'femcee' and Indigenous Music Officer for the Music Managers' Forum are also well-established figures. In 1993 Munki Mark founded multicultural hip hop collective South West Syndicate, an extended family of a crew which included a quadriplegic Lebanese-Australian MC as well as Pacific Islander, Croatian, German, Lebanese and Anglo members at various times. SWS played a major part in 'Hip Hopera', a western Sydney community hip hop project directed by Morganics and Urban Theatre Projects in 1995. 'Hip Hopera' was a watershed for Sydney hip hop, and SWS subsequently won a Deadly Award in 2003, shortly before they broke up. In 1997 they gave a high-powered live performance at Granville Town Hall as part of the Hip hop for Palestine event, which was filmed by SBS but never screened. They were also involved in A place of peace, a three week hip hop project filmed by Penny Nutt for the ABC's Indigenous Unit in 2001, which was held at the Settlement Neighbourhood Centre in Redfern, funded by the New South Wales Department of Education and Training. This included as facilitators Morganics, Lez Beckett, Fijian-Australian MC Trey and Elf Transporter, another hip hop pedagogue who rapped with Morganics in the important Sydney group MetaBass ${ }^{\prime} N^{\prime} B r e a t h$, and is now based in Melbourne with the workshop facilitators Lab Rats and the militant ecologist hip hop crew Combat Wombat. ${ }^{3}$

After SWS broke up, Mark, a fair-skinned Koori who also has German and Irish heritage, and who has been described by BrothaBlack as 'the architect of Aboriginal hip hop', began working with the New South Wales Department of Education and Training, and he has participated in the Indij Readers series. This has produced educational books by New South Wales Aboriginal role models and elders such as Anthony Mundine, Michael O'Loughin, Adam Goodes and Cath Farrawell. Mark published the primary school text Raps 4 little fullas which comes with a CD, based on his workshops in Bogabilla. These led to the formation of a pre-teen hip hop group called the Bogabilla Thrillers who have 15 members and have performed numerous gigs in southern

3. Nutt 2001. (Also released as a CD, Hip Hop, A Place of Peace, Self-produced, 2001). 
Queensland and northern New South Wales. Raps 4 big fullas is the secondary school version, a colourful collection of rap lyrics and graffiti design which deal with a trip to the city, life in northern New South Wales, Aboriginal role models in sport, such as Cathy Freeman, a game of football, breakdancing and place names. It also contains a long piece entitled 'Dreamtime', lyrics superimposed over colour photographs of rocks and waterways, about the importance of Aboriginal accounts of Australian history:

Aboriginal life always filled with songs of history

Laws and customs, no mystery

White man found a happy healthy people and

It took 50 years to civilise them off the land

First Fleet officers cashed up with publishing fees

Mixed fact and fiction in their biographies

Observed, captured, examined, kept as slaves

Then killed if we misbehaved ${ }^{4}$

Another piece entitled 'Dreamtime' concludes with a plea to maintain traditional Aboriginal culture:

Once the corroboree is gone, we're finished

So the importance should never be diminished

Nor should the songs or stories from the old days

Shouldn't have to surrender our culture or old ways

Total disrespect for our culture and meantime

I wish I could go back to the Dreamtime. ${ }^{5}$

Raps 4 big fullas includes a story in the Gamilaraay language, along with an English translation, about a grandmother and granddaughter catching a fish from the creek, cooking it and eating it with crayfish, turtle, shrimp and yams with the rest of the family who have returned home from relatives in Gunnedah. ${ }^{6}$ MunkiMark has also rapped in his grandmother's language, Jardwadjali, the language of the Grampians in Western Victoria, in Arrernte, spoken in Alice Springs (SWS's track 'What A Place' has lyrics in Arrernte), and picked up bits of Wiradjuri, Gamilaraay and Uliraay in his travels. As he has said:

We try to go toward a corroboree sort of thing. Aboriginal language was never a written language; it's always been an oral and visual language, stories being passed down through rituals, corroborees, song and dance. Hip hop fits in quite well with that, and Aboriginal hip hop is out there and all the communities know about it. The elders know that Aboriginal hip hop exists and are keen to get us people into their communities to show the kids that they can get their own people doing it. ${ }^{7}$

Despite having been extensively indigenised in almost every culture around the world, rap and hip hop are still perceived in the public sphere and through mass media as primarily African-American musical forms. The mainstream manifestations of vio-

\footnotetext{
Monkey Mark 2004: 11.

Monkey Mark 2004: 14.

Monkey Mark 2004: 20-21.

7. Interview with MunkiMark, conducted by Tony Mitchell, Alastair Pennycook and Nick Keys, 4 November 2005, Klub Koori, Sydney University.
} 
lent posturing, machismo, misogyny, ostentatious wealth (bling bling), pimping and brutality, which are still embedded in the dominant sounds and images disseminated around the world in music videos and on commercial radio stations, provide fuel for politicians and pundits alike to blame it for youth moral panics from the Lebanese-Australian youths rioting in Cronulla in December 2005 to the earlier demonstrations by Arab and North African youth in France. ${ }^{8}$ Aspirational prime minister Peter Costello even blamed it for what he referred to in a speech to the Hillsong Church in Sydney in 2004 as the 'moral decline' of Australian youth. But Aboriginal hip hop practitioners, and the many other forms of what might be called 'native' Australian hip hop, which have been simmering underground over the past two decades, demonstrate that the four elements of hip hop - graffiti, breaking, DJ-ing and MC-ing - are often highly positive, even educational forces. They have certainly provided important voices and vehicles of self-expression for disenfranchised and disadvantaged young people from a wide range of different ethnic backgrounds in Australia.

In MunkiMark's case, as for some Maori and Samoan MCs in Aotearoa/New Zealand, hip hop has also provided a means of retrieving and giving public voice to indigenous languages, history and cultural forms. MonkiMark has mentored Palestinian-Australian MC NOMISe, who played an MC and petrol head in Kim Mordaunt's feisty film about Lebanese-Australian youth in Bankstown, Jammin' in the middle E, which was screened on SBS in February 2006. NOMISe also took part, along with BrothaBlack, Samoan performer Leo Tanoi and Torres Stait Islander actor Aaron Fa'Aoso, in Back home, a powerful theatrical exploration of masculinity directed by Alicia Talbot which Urban Theatre Projects produced at the 2006 Sydney Festival. Audiences were bussed from the Riverside Theatre in Parramatta, along with an Aboriginal guide, to an outdoor theatre at the Oakhurst Neighbourhood Centre, on traditional land of the Dharug people. There the stage was set for a backyard barbecue where the four men have a party, perform songs and raps, and gradually reveal their shattered lives to one another.

Hip hop has played a strong educational role in Aboriginal communities. In 1999 MunkiMark and Brotha Black joined forces with Morganics in 'Desert Rap', a three week workshop with Aboriginal young people in Alice Springs which was set up by Triple J's Top End correspondent Tony Collins. The workshops were the subject of a documentary film broadcast on the ABC, featuring, among other elements, a brilliant performance from Swanz, an all-female crew, of a track called 'Brown Skinned Black Woman'. ${ }^{9}$ The facilitators insisted on no American accents, or as Mark puts it, 'don't be a yo yo, ${ }^{10}$ and participants were encouraged to find their own voice, their own accent, their own language. This led to a number of other similar 'desert rap'-styled workshops, including 'Hip Hop Up Top' in 2001, which Collins also set up, working with Aboriginal young people in Darwin and Arnhem Land. At times Morganics and

8. See Stevenson and Tavros 2005: 7. The article tries to suggest that murdered MC Tupac Shakur and US gangsta rap - a genre which died out around 1995 - were inspirations for 'a very ugly manifestation of cultural chauvinism' displayed by Lebanese-Australian youths in the Cronulla riots.

9. Collins 2000.

10. Interview with MunkiMark, conducted by Tony Mitchell, Alastair Pennycook and Nick Keys, 4 November 2005, Klub Koori, Sydney University. 
MonkiMark have found themselves working with young Aboriginals for whom English is their fifth language.

\section{US and local influences}

In their all-too-brief section on Aboriginal hip hop in Deadly sounds, deadly places: contemporary Aboriginal music in Australia, Peter Dunbar-Hall and Chris Gibson suggest that the 'black transnationalism' of African-American hip hop, especially those few artists who sought to make connections with Aboriginal communities when they toured Australia, was a decisive factor in the development of hip hop by Aboriginal practitioners. They quote MC Lez Beckett:

before Australian and Aboriginal hip hop really took off, we [Aboriginal youth] all followed what the Americans did. It really influenced me because it was a black face on television, and when you are a young fulla growing up in Cunnamulla in central Queensland, it is a pride thing to see another blackfella in a position of power. ${ }^{11}$

African-American hip hop artists who influenced MunkiMark include 'old school' crews and MCs like Run DMC, the Sugar Hill Gang and Grandmaster Flash, along with Public Enemy and Ice T - both of whom he has met up with in Sydney several times and the 'speed rap' of Fu Schnickens. But he reserves a special place for 'conscious' MC Michael Franti of Spearhead, and formerly the Disposable Heroes of Hiphocrisy, a fairly regular visitor to Redfern over the past decade. Like Franti, Mark sometimes plays acoustic guitar when he raps, and number of other Aboriginal MCs such as Lez Beckett, Brotha Black, the Sydney-based rapper MC Wire, aka Will Jarratt, a Gumbayngirri descendant from Bowraville, and political femcee Jakalene Extreme (also known as Shazza on the SBS comedy Pizza), do likewise. This suggests that the guitar-based country music embraced by Aboriginal people over the past half century may be just as influential on some hip hop by Aboriginal artists as the hip hop of their African-American counterparts. It is also one aspect of the way in which Aboriginal MCs are referring to the historical development of Aboriginal culture in Australia in their own indigenous lyrical poetics and signposts.

\section{Klub Koori}

Many of the prominent Aboriginal hip hop artists of recent times took part in Klub Koori, a showcase for Aboriginal hip hop which was organised by Koori Radio and the Gadigal Information Service at the Manning Bar at Sydney University in November 2005. Performers included Ebony Williams, a descendant of the Wirdjuri Tribe, who also has African-American parentage, and got her start at age 15 in 'Hip Hopera' in 1995 in a duo called Two Indij. She opened her performance with 'And the Beat Goes On', a track first released in 2003 on a compilation put out by the Sydney-based Mother Tongues collective, which claims to be the only all-women hip hop label in the world. Ebony's assertion of Aboriginal rights speaks of a history of denial:

As a young black woman / I have to make my point more stronger / So it'll encourage others to recognise / They're part of what we've been denied for many years / As hip hop makes me stronger / Hopefully you will understand you have

11. Lez Beckett cited in Dunbar-Hall and Gibson 2004: 123. 
to wake up / If you want something before you're left behind ... Don't let your dreams dry like glue / Stick with it! ${ }^{12}$

She followed this with 'You Never Seem to Understand Me', which dates back to Hip Hopera days, a more personal track about family discord, which like Munki Mark, seeks solace in the Dreamtime:

Family is family, so why the fighting / Our race should stick together / When families are uniting / That's what our elders are stressing to us / As they teach and explain / The ways of the Dreamtime. ${ }^{13}$

'Open Up Your Mind' is a track with a didjeridu riff from 1999, which starts its history lesson 200 years ago with the white invasion of Australia and its traumatic consequences for Aboriginal people, including the stolen children. The final two verses are a sustained 'diss' of Pauline Hanson:

You're trying to hold my people to ransom / Dancing with the devil, Pauline Hanson / ... She don't like my people / In her eyes they're never going to be equal ... Wanting me to feel out of place in my own country ... A high profile trouble maker / Go back to selling fish in your stupid shop! ${ }^{14}$

BrothaBlack then stated his aim is to 'put my people on the map'. As he has said 'I started out by trying to imitate Chuck D [of Public Enemy] and people like that. Listening to rap music was just part of my everyday life. ${ }^{15}$ More recently, he came to the defence of his workshop cohort Morganics when the latter was attacked on the Vibe Aboriginal and Aussie Hip Hop forum as 'wack cant rap an need to stop messin up our kids by tryin 2 teach them to rap, gubba tryin 2 teach black music? [sic]' BrothaBlack's response spoke for the hundreds of Aboriginal MCs Morganics has tutored:

that's my boy you're talking about (Morganics) so what if he's white he's doing good in our community, which is a lot more I can say than what other people are doing at the moment. If you going to put him down you have got a few more people to have a go at because there's quite a few white fullas in Aboriginal music and not just Hip Hop (Think about it). If you think he's in it for the money and Kudos your wrong I can back that up $100 \%{ }^{16}$

In 'Brotha's Back' he gives 'shout outs' to Condell Park and Bankstown, acknowledging the historical origins of Aboriginal hip hop in Sydney. A group of Koori women is dancing to his beats as smoke billows through the red, blue and green lights. A scratch DJ goes into action as BrothaBlack raps 'This is more than history, it's my identity / A new generation, the indigenous nation / Calling out to my people ... We fight for the rights of our population. ${ }^{17}$

12. Various artists 2000; Various artists 2003.

13. Various artists 2000; Various artists 2003.

14. Various artists 2000; Various artists 2003.

15. Koori Mail, 27 November 2002: 33, cited in Dunbar-Hall and Gibson 2004: 123.

16. Vibe Forum - Aboriginal and Aussie Hip Hop http://deadlys.vibe.com.au/forum/ topic.asp?TOPIC_ID-108 (Accessed 6/9/05).

17. 'Brotha's Back' is on the Triple J compilation The Hip Hop Show, Warner/ABC Music 2005, as is Local Knowledge's 'Murri Flows'. 
For his last number he is joined by Ozi Battla, an Anglo MC from militant multicultural Sydney hip hop crew the Herd, the two MCs gripping each other's hands in solidarity as they swap rhymes.

\section{Local Knowledge: Blackfellas in the house}

Lez ('Bex') Beckett's set is heralded by two didjeridu players and traditional dancers in bodypaint, tracing the movements of kangaroos, among other gestures, demonstrating the adaptability of hip hop into traditional Aboriginal storytelling and dance. Beckett, a veteran of numerous educational hip hop workshops which involve teaching English to Aboriginal youth through hip hop, performs tracks from his new EP, We Were Soldiers, and there is even more dancing now. But the act everyone is waiting for is Local Knowledge. As Joel Weintraub, originally from the Kabi Kabi tribe in south-east Queensland, MC with Local Knowledge and lecturer in Health Sciences at Newcastle University, told Australian Music Online, Local Knowledge is primarily 'about getting young blackfella mob back into their culture and teaching our history through music' ${ }^{18}$ Their track 'Blackfellas', for which they completed a video in Redfern in October 2005, was on high rotation on Triple J for two months, and is the feature track of their debut EP, which they have been selling at gigs, and has already gone into a second pressing. ${ }^{19}$ It starts with a shout out to all the Aboriginal groups throughout Australia: Kooris, Murris, Noongah, etc. They sometimes even throw in 'Maori', in commemoration of the numerous Maori immigrants in Australia and the Indigenous Down Under workshops they did with Maori crew Upper Hutt Posse in Wellington, Aotearoa, in 2003. The video shows them driving through Redfern with tribal names tattooed on their arms, in a style more reminiscent of the Maori film Once were warriors than US gagsta rap. As group member Abie Wright told me, they are influenced by Maori and Pacific Islaner hip hop like Nesian Mystik, Che Fu and Upper Hutt Posse: 'Upper Hutt Posse are deadly lads and they are pretty staunch about their culture, their history and their identity, and they stand up and say what needs to be said, which is basic human rights as far as they are concerned.' Wright is also an aficionado of Crump, 'Dirty Southern' hip hop from the Mississippi as practiced by Lil' Jon and the East Side Boys. As he explains:

it's a form of hip hop, but it's repetitive with lots of screaming. It's sort of like Zulu chanting, with a heavy bass going through it. To us it's like when we were sitting around singing corroboree songs. Them fellas with their Zulu chants and us fellas with our old people sitting around and stomping on the ground 'boom boom boom', it saves us from letting our aggression out through our fists. ${ }^{20}$

This undercurrent of anger comes out in 'Who's Gonna Stop Me' from the EP - a track based on an incident where some Aboriginal people were barred from a nightclub in Newcastle, referred to as 'savages' and refused to take it lying down. The chorus, 'Who's gonna stop me - Nobody!' is repeated with increasing intensity until the track finally winds down into slow motion. Brothers Abie and Wok Wright both have a background in rugby league and traditional Aboriginal dance; as Wok says:

18. Interview with Joel Weintraub, Australian Music Online, 12 December 2005 www.amo.org/ au/qa_interview.asp?id1054.ott.gen.muso (accessed 24/12/05).

19. Local Knowledge 2005.

20. Interview with Local Knowledge, conducted by Nick Keys and Tony Mitchell, October 2005, Manning Bar, Sydney University. 
Me and Abie laugh about it a lot because we try and structure our shows like we used to structure our corroboree shows. We'd start out with a bang, with a spectacular dance, and then we'd slow it down in tempo, then we'd do a strong dance, a slow one, and then we'd go into something leftfield - a hitch hiker's story on a didjeridu. $^{21}$

Tonight they begin with their website back-projected on a large screen, featuring the group surrounded by flames, accompanied by series of heroic brass fanfares, and a rather drawn-out fire-making ceremony. Then the three of them leap onto the stage, jumping up and down, left arms whirling in unison, right hands gripping their mics, goading the audience into action - 'Are you ready to rumble? We'll shake the world!' They perform the tracks 'Rumble' and 'Murri Flows' off the EP, with some didjeridu accompaniment, and hit their peak in a triumphant version of 'Blackfellas' which has everyone up on the dancefloor. They're playing down the more educational side of their repertoire tonight - health promotion songs about alcoholism and sexually transmitted diseases, for example - in favour of the less confrontational and more 'feelgood' tracks. As Wok explains:

A lot of our early stuff was just rapping about straight-up, hardcore issues, about the stolen generation, about being hassled by coppers, all that sort of stuff. We just wanted to make the kids know that there is still a lot of work to be done, and we can't lose them to drugs and alcohol, just to tell them they do have a role to play. ${ }^{22}$

This side of the group was shown on the 2004 SBS 'Blaktrax' program, Local Knowledge: the message, which provided a useful background to the group's development as an educational crew in Aboriginal communities since they formed in March 2002, as well as the way they use Aboriginal English and diss American 'wannabees' ${ }^{23}$ But as Wok emphasises, there is a negative side to the educational aspects of hip hop which sometimes conflicts with its enjoyment:

I like the more commercial stuff to be honest, the feelgood stuff, just because I don't like reminding the kids of how when they get home from school, there is no food, dad's hitting mum, mum's hitting dad, so they go into their room and put music on, they don't want to hear anyone singing about that. They want to go on a journey with their music. So that's one thing we do, the easy going feel, but we have a bit of a go at everything - Abie likes his crump, Joel's a straight hip hop lover, as well as reggae and ragga. ${ }^{24}$

Weintraub emphasises the popularity of hip hop in Aboriginal communities as well as its similarity to existing Aboriginal traditions of song and dance:

In our communities storytelling, music, dance, creative arts are the only form of communication, it's the way we've passed on our knowledge, and that's one of the big reasons hip hop is huge in Aboriginal communities. There isn't one Aboriginal kid who doesn't like hip hop because it's that oral communication that

21. Interview with Local Knowledge, conducted by Nick Keys and Tony Mitchell, October 2005, Manning Bar, Sydney University.

22. Interview with Local Knowledge, conducted by Nick Keys and Tony Mitchell, October 2005, Manning Bar, Sydney University.

23. Flanders 2004.

24. Interview with Local Knowledge, conducted by Nick Keys and Tony Mitchell, October 2005, Manning Bar, Sydney University. 
we've been used to over thousands and thousands of years. And you can also dance to it, which is a bonus! ${ }^{25}$

One educational project which Local Knowledge was involved in is 'Young, Black + Deadly', a series of workshops in all genres of music in a variety of Sydney locations for young Koori musicians. This was organised by the Gadigal Information Service and culminated in concert finales at the Enmore Theatre and CD releases. As Abie Wright has stated, 'YBD is our way of making sure that Koori music and young Koori artists keep developing through to the next generations. It's our traditional way of teaching' ${ }^{26}$

\section{The Aboriginal hip hop legacy continues}

Local Knowledge's recent success has drawn attention to the increasing number of younger Aboriginal hip hop practitioners, especially in Brisbane, who are using hip hop to explore their own identity and to get in touch with traditional aspects of their culture. Indigenous Intrudaz, a trio from Glenala State High, were nominated for a 2005 MusicOz award in hip hop, and their track 'Clap Your hands', about growing up on the wrong side of the tracks in Brisbane, was a finalist in Triple J's Unearthed competition. MC Murriz, a teenage trio, released an EP, Ain't No Suckers, in 2004, which expressed pride in their Aboriginal heritage as well as in Brisbane, and brought them radio airplay, particularly for their track '2Black 2Strong'. They have performed at Brisbane's Stylin' Up festival, which has been something of a showcase for recent Aboriginal hip hop, including groups like MIZ, a female duo who consist of Torres Strait-born Sarah Patrick and Seychelles-born Marsha Chang-Tave. MIZ's track 'Where It's At' had Triple J airplay. MC Dizzy, aka Charmaine Doolan, is a Townsville-born Murri now based in Brisbane.

But the senior exponents of Brisbane Aboriginal hip hop are undoubtedly Native Rhyme Syndicate, who formed in 1994, and were nominated for two Deadly Awards in 1998. One of the group's members, Daniel 'DK' Kinchela, comes from the Gummilaroi clan and is a cousin of Wok and Abie Wright's as well as lead MC with a new crew, Tribal S.U.N.S regime. Native Rhyme's main MC, Cameron 'C-Roc' Callope, is from the Gkuthaarn clan in the Gulf of Carpentaria, and was appointed an elder of his clan for the work he has done in educating Aboriginal youth through hip hop. The group started recording in 1998 on a compilation called Emerging Artists with a cover of 'Chain Remains' by African-American hip hoppers, Naughty By Nature, whom they played support for in Brisbane. They followed that with 'Together', a collaboration with Kev Carmody and the Cruel Sea on the 2003 Corroboration compilation. 'We'll Always Love you' is a memorial for a dead friend, which was included on the 2004 Redhotgreenblack environmental awareness compilation UnAustralian. The Rockhampton-based Torres Strait Islander crew Stray Dogs have also celebrated their heritage with a track called 'Saltwater People'.

In Melbourne, Little $\mathrm{G}$, also known as the Wogarigine, due to her mixed Greek and Aboriginal background (her real name is Georgina Christanthopoulos), illustrates the crossover between Aboriginal and multicultural hip hop. This also occurs in Perth

25. Interview with Local Knowledge, conducted by Nick Keys and Tony Mitchell, October 2005, Manning Bar, Sydney University.

26. Young Indigenous artists from NSW 2005. 
crew Downsyde, whose members come from Aboriginal, Middle Eastern, South American and other backgrounds. Little G, as George Stavrias has noted in his 2003 Honours thesis at Melbourne University, has written and performed tracks about Aboriginal deaths in custody as well as the Yorta Yorta tribe, which she initially believed was where her mother came from, until she discovered otherwise. As Stavrias points out, Little G's 'entry into hip hop occurred simultaneously with her desire to learn about her Aboriginal heritage'. ${ }^{27}$ She started exploring her Aboriginal side after she began taking lessons in Aboriginal Cultural Studies from an elder, but her negotiation of her Aboriginal identity was a complex and difficult process, compounded by her mixed heritage and involving a great deal of anger as she learned about past massacres and the treatment of Aboriginal people throughout Australian history. Hip hop became a means of channeling this anger, as well as encouraging younger Aboriginals to be proud of their heritage. As she has said:

Hip hop for me is like another form of boxing, except lyrically ... The young people will not learn through schools to be proud of themselves, so if we can do it through music, or film, or art, that's the right choice. ${ }^{28}$

Little G was one of the protagonists of MC Que and Colleen Hughson's 2004 film All the Ladies, which profiled six Australian women MCs, most of whom come from mixed non-Anglo heritages, and she sometimes performs with Melbourne multicultural groups Curse ov Dialect and TZU. Nonetheless she feels doubly marginalised from much of the Melbourne hip hop scene due to her identification with her Aboriginal heritage, and her association with 'conscious' or 'felafel' rap:

You get the ockers, the wogs, the felafel rappers which is us, you know on the outside, the bloody hippies. I don't ever think I'll be accepted by everyone, because I'm indigenous, and they're all gonna always compare me with overseas. ${ }^{29}$

Stavrias concludes his study, which also contains a chapter on Morganics and MC Wire, with the following statement. It demonstrates the importance of hip hop as a means of helping Aboriginal youth to negotiate their identities and to connect with traditional forms of culture, as well as continuing storytelling traditions:

Negotiating tradition and modernity, Aboriginal culture is actually a culture in the making and hip hop is a powerful tool in helping Aboriginal youth with this negotiation. Sampling and representin', characteristics which ground it in the local, allow traditional sounds into the music, traditional dances into the breakdancing, and traditional values and language into the raps. The rap itself enacts traditional knowledge through storytelling. Yet hip hop as a medium for identity recognition is not limited by its attachment to traditional forms. Inspired by the African American oppositional politics it provides an avenue for Aboriginal youth to discuss their concerns in a manner that is not only fashionable, but also empowering. Importantly, it is energised by that key ingredient for youth and children - having fun. ${ }^{30}$

27. Stavrias 2003: 17 .

28. Interview with Little $G$, conducted by Colleen Hughson (Hughson and Quinsacara 2003).

29. Stavrias 2003: 24 .

30. Stavrias 2003: 50 . 


\section{Wire: the modern day corroboree}

Hip hop's connections with traditional Aboriginal and Torres Strait Island culture are perhaps best expressed by MC Wire, who told Moses Iten in 2003:

This is my lyrical healing. I can't go and get scarred any more and I can't become a traditional man. I'm a modern day blackfella, this is still Dreamtime for me. Hip hop is the new clapsticks, hip hop is the new corroboree. ${ }^{31}$

Wire was the subject of a personal documentary-essay film by Australian Film, Television and Radio School graduate Grant Leigh Saunders in 2005 entitled B.L.A.C.K: an Aboriginal song of hip hop, which takes its title from what is probably the best-known track performed by Wire, and is also an anagram for 'Born Long Ago Creation's Keeper'. ${ }^{32}$ In the track Wire interrogates what being black means to him today, regarding it as a positive thought process through which he explores his own identity and relates it to Aboriginal history and tradition, including contemplating the Aboriginal massacres of the past. As he explains:

It's not just my skin colour, for even the blackest brother can be white. You see black is a thought process, for me a way of life. To be black is to be free, free from the heart, free from the head. Free to take that man for what he is, free to choose and make my own decisions. ${ }^{33}$

Wire usually reverses his name to Wire $\mathrm{MC}$, where ' $\mathrm{MC}^{\prime}$ does not stand for the usual 'Master of Ceremonies or 'Microphone Chief', but rather 'My Cousin', emphasizing Aboriginal family connections. He appropriates hip hop into Aboriginal culture as a 'modern day corroborree':

It's still the same corroboree, still singing and dancing and telling the same stories about the immediate environment. So it's not a new corroboree, it's just a modern day corroboree. It's still an old art form - for want of a better term. ${ }^{34}$

In his track 'B.L.A.C.K.' (Born Long Age Creation's Keeper), which he performed a cappella for me during an interview in Victoria Park, Sydney, as no recorded version of it exists, he is explicit about hip hop's resonances with Aboriginal traditions:

I feel a rhythm in the forest and it's totally bliss,

Words float like a mist through a valley that's thick,

Memories of corroboree, didjeridu and clapstick,

Melaleuca and the eucalypt to cure the sick,

From a mountain to the ocean flows a river through the forest,

Running naked through the bush like the ancient ones before us,

I can hear the chorus of the corroboree calling me,

Yes I am the fruit of the Murabi tree see,

I often wonder what my name would have been,

Living in the dreamtime with my ancient tribal kin,

31. Iten 2003: 78-81.

32. Saunders 2005 .

33. MC Wire, quoted in Message Stick http://www.abc.net.au/message/radio/awaye/ ms_opera/music_mcwire (accessed 26/12/05).

34. Interview with MC Wire, conducted by Nick Keys and Tony Mitchell, 31 March 2006, Victoria Park, Sydney. 
Hunting and gathering, living this way,

Playing tribal rhythms through the night and into day.

But reality cuts, interrupts my fantasy,

As I casually step into the jungle of humanity,

Maintain my sanity while I'm constantly under the scrutiny

Of Police and Security, they shooting me

But don't be stupid see, stereotyping is just like executing me.

It's a modern day corroboree, you know how we do,

Shake a leg, lift your head, represent, stay true,

Brother stay black, sister stay beautiful,

Let 'em know that you be Aboriginal and proud,

Right now no shame in here,

Lights out, flash black, I'm bringing flame this year,

The sounds you hear right now is right here and now

And I' $m$ here right now, it's the brand new brown. ${ }^{35}$

Wire also refers to himself as an 'abo-digital' MC in a way which combines modern digital music technology with traditional Aboriginal handcrafts. His capacity to rap outdoors without any technological support embodies his connection with traditional storytelling:

'abo-digital' has an ambiguous meaning because of the word digital. I'm abo-digital because I'm a twenty-first century Aboriginal, I'm down with laptops and mobile phones and home entertainment. But digital also means your hands and your fingers, so I'm still putting my fingers in the dirt; I'm still using my hands to create things. So that's the ambiguity. ${ }^{36}$

Saunders' film incorporates clips of footage of Local Knowledge, 'The Block', a track about Redfern devised by Morganics with young Aboriginal pupils from Fort Street school, MC Murriz's '2Black 2 Strong', as well as the pre-teen Morganics-produced Wilcannia Mob's celebrated 2002 track 'Down River'. He explores his own personal history as a fair skin Koori in the film through hip hop, 'which gave me back what they stole from my past'. He also traces a history of Aboriginal hip hop back to the 'old school breakers' of 1982, interviewing Leonie Morcombe (aka Leapy), Ralph Saunders and Sean Choolburra, who reinforce the importance of the 'no shame factor' of breakdancing and its expression of the centrality of dance to Aboriginal culture. He namechecks B Boys Venom, 2 Ezy, Lama Rock, Dougan, Ninginaas and DJ Vilas, who like many other B girls and B boys around the world were greatly influenced by the Rock Steady Crew, a group with a high proportion of Latino Americans rather than African Americans. In the film Wire also explains the predominant focus of Aboriginal hip hop on MC-ing and breakdancing rather than DJ-ing and graffiti by the fact that most Aboriginal hip hoppers can't afford turntables, and Aboriginal graffiti artists 'would just get locked up for life'. He adds that hip hop is his own way of sublimating feelings of anger and frustration, echoing Little G and Local Knowledge: 'If I didn't put

35. Interview with MC Wire, conducted by Nick Keys and Tony Mitchell, 31 March 2006, Victoria Park, Sydney.

36. Interview with MC Wire, conducted by Nick Keys and Tony Mitchell, 31 March 2006, Victoria Park, Sydney. 
pen to pad, I could be putting fist to face.' And he has also pointed out a significant difference between Aboriginal hip hop and Australian hip hop, and implicitly US hip hop:

The difference I find between Aboriginal hip hop and white Australian hip hop [is that] we have a deep innate sense of community obligation, we are born with it, and that's why you don't hear black MC's - I can say all of the ones I've come across - using words like 'bitches', they won't diss women. Because my mum isn't a bitch, my grandma isn't a bitch, and the mother the land ain't a bitch. You know what I'm saying, that's a big dividing line ... I find Australian hip hop is too preoccupied with getting mainstream support. For myself personally, I don't give a fuck about mainstream support because I come from a place where the mainstream has never supported me anyway. And I don't do this to advance hip hop, I do it to advance myself as a human and as an Aboriginal, advance the awareness of my culture, especially on a contemporary tip. ${ }^{37}$

As an educational format, a vehicle to express anger at discrimination and marginalisation and pride in one's heritage, a way of binding communities together through dance and performance, a declamatory form of storytelling set to music, and above all a means of expressing oral history, hip hop's affinities with Aboriginal cultural forms make it an ideal means for youth to get in touch with their tribal identity, history and cultural background. It is also a vital means of articulating their place in today's world and expressing an epistemology; as Wire has stated: 'There are ... literacy skills involved if you want to rap or write. It's also a form of education for yourself, self-knowledge. 38

From its origins in toasting and sound systems in Jamaica in the 1970s, hip hop has been extensively globalised and indigenised in a plethora of contexts, in the process of being incorporated into local languages and cultural forms. In Greenland, the Inuit crew Nuuk Posse rap in a mixture of Greenlandish, Danish and English, and incorporate whale songs and throat singing into their hip hop. In Aotearoa/New Zealand, Te Kupu and the Upper Hutt posse perform and record in the Maori language and sample pre-European Maori musical instruments such as the purerehua (bull roarer), while Feel Style raps in Samoan. In Argentina, El Sindicato Argentino del Hip Hop express 'blood, sweat and rage' about issues such as money and the hard times their country is experiencing. 39

Its appropriation into the world's oldest living form of traditional culture was inevitable. As Wire put it: 'Hip hop is a part of Aboriginal culture, I think it always has been. $^{40}$

37. Interview with MC Wire, conducted by Nick Keys and Tony Mitchell, 31 March 2006, Victoria Park, Sydney.

38. Interview with MC Wire, conducted by Nick Keys and Tony Mitchell, 31 March 2006, Victoria Park, Sydney.

39. Sindicato Argentino del Hip Hop 2005. Apart from the titie track, this CD contains tracks entitled 'El Dinero' (Money) and 'Tiempos Dificiles' (Hard Times).

40. Interview with MC Wire, conducted by Nick Keys and Tony Mitchell, 31 March 2006, Victoria Park, Sydney. 


\section{References}

\section{Written sources}

Dunbar-Hall, Peter and Chris Gibson 2004, Deadly sounds, deadly places: contemporary Aboriginal music in Australia, UNSW Press, Sydney.

Iten, Moses 2003, 'All you mob, get into this', Juice, April: 78-81.

Monkey Mark 2004, Raps 4 big fullas, Indij Readers, Sydney.

Maxwell, Ian 2003, Phat beats, dope rhymes: hip hop down under comin' upper, Wesleyan University Press, Middletown.

Stavrias, George 2003, 'Identity and appropriation in Aboriginal Australian hip hop', Honours thesis, Department of English with Cultural Studies, University of Melbourne.

Stevenson, Andrew and Edmund Tavros 2005, 'Years of rejection erupted in open rebellion', Sydney Morning Herald, 17-18 December 2005: 7.

\section{Film and television}

Collins, Tony 2000, Desert rap, ABC TV.

Flanders, Kris 2004, Local knowledge: the message, SBS TV.

Hughson, Colleeen and Mary Quinsacara 2003, All the ladies, video documentary, Hughson Gyrl Productions, Melbourne.

Nutt, Penny 2001, A place of peace, Message Stick, ABC Indigenous Unit.

Saunders, Grant Leigh 2005, B.L.A.C.K : an Aboriginal song of hip hop, Australian Film Television and Radio School.

\section{Music}

Local Knowledge 2005, Blackfellas, Propaganda Recordings.

Sindicato Argentino del Hip Hop 2005, Sangre, sudor y furia, Machete/Universal. Sound Unlimited 1992, A postcard from the edge of the under-side, Columbia/Sony. Various artists 2000, First words, Mother Tongues/Creative Vibes CD. Various artists 2003, Mother tongues, Quartermass CD.

Young Indigenous Artists from NSW 2005, Young, black + deadly Volume 1, Gadigal Information Service CD. 